\title{
Translation and Culture in the View of Contemporary Chinese Scholars
}

\author{
Meng Xia* \\ Shaanxi Normal University \\ 199, South Chang'an Road, Yanta District, Xi'an 710062, China
}

Received 18.09.2015, received in revised form 02.11.2015, accepted 30.11.2015

Culture issues in translation have attracted increasing attention among Chinese translators since 1980s. On the basis of modern translatology, Chinese scholars have done a series of fruitful researches on translation from many perspectives including culturalogy, cross-cultural communication and cultural linguistics. Chinese are deeply influenced by Chinese cultural philosophy. They stress on the "degree" of development and evolution, which directly results in traditional Chinese translators' conservative subject consciousness in their translations. In China, since cultural factors were taken in to consideration in theoretical study of translation, to many translators, information collection and logical positivism are not incompatible.

Keywords: translation and culture, cultural integration, cultural transplantation.

DOI: 10.17516/1997-1370-2015-8-12-2901-2907.

Research area: philology.

\section{Introduction}

Cultural communication between Chinese nation and other people enjoys a splendid long history in which numerous world famous translators and translation theorists gained their reputations. From Xuan Zang to Yan Fu, from Lin Shu, Lu Xun, Qu Qiubai to Fu Lei, Chinese scholars represented by these figures developed traditional Chinese translation works and established the foundation of translatology with distinctive Chinese features. However, "traditional Chinese translation study is obviously a closed system rather than an open, synthetic, interdisciplinary and systematic one." (Liu, 1990) After 1970s, research findings of translation studies and contemporary linguistics were gradually introduced to China from America, France, Russia and many other countries. Chinese scholars have finished the translation of almost all the major works of translation theory around the world in the later decades. With the worldwide trend of culture turn in translation study, Chinese translators began to pay attention to the cultural issues in translation both in theory and practice.

\section{Relationship between Translation and Culture}

Early Chinese translators and translation theorists have been aware of the close relationship between translation and culture. Yan Fu, the father

(C) Siberian Federal University. All rights reserved

* Corresponding author E-mail address: meng003@163.com 
of Chinese modern translatology, proposed his 3-character translation principle -- "faithfulness, expressiveness and elegance" (Yan, 1880) during the process of his introduction of western sociology, politics, philosophy and natural science to China, which exerted a far-reaching influence on Chinese translation for many years. While, the real cultural study in translation in China was triggered by international theoretical study of translation. From 1980s, Chinese translation circle began to strengthen the communication between Chinese and Western translation theories. On the basis of traditional Chinese translation theory, with Chinese language, culture and special thinking pattern, a distinctive research feature was established

Culture study in translation started from Chinese scholars' doubt about a popular view on translation in early days -- "Translation refers to the transformation between two different languages." (Liu, 1982) People began to realize that the ultimate purpose of translation is to serve cultural communication. The differences of dictions, thinking patterns and ways of expression among people are all resulted from different cultural traditions. Thus, seeking linguistic equivalence only is far from a correct attitude in translation. Thoughts and cultural communication should be taken into consideration when translating. Consequently, translation study from cultural perspective is of great importance. (Wang, 1984) When culture is taken into consideration in theoretical study of translation, the nature of translation is no longer about the conversion of different languages.

Concerning the relationship between translation and culture, the significance of culture to translation has gained an increasing attention among Chinese researchers. It is widely believed that a translator should be a person having a great knowledge of culture. The combination of translation study with the new discipline of comparative culture may create a new dimension to cultural study in translation. It will be beneficial for the cross-cultural communication activities by providing a more panoramic perspective. (Wang, 1984) The formation of new horizons of a nation's language and culture in the conflicts and integration of two different cultures is the aim of translating. The mission of translators who are engaged in a job closely related to culture is to make the target language readers accept the most artistic information of the original work ( $\mathrm{Wu}$, 1988)

In the $21^{\text {st }}$ century, Chinese scholars further realized the intimate relationship between translation and culture. To them, translation itself is a kind of cross-cultural communication activity. In verbal communication, people are always confronted with many language expressions with distinctive national cultural features, and translation problems thereby come into being. Cultural difference is the source of the obstacles and difficulties in translation, since every language is strictly restricted by its culture. Different language comes from different origin. They show their own culture, custom and characteristics. ( $\mathrm{Du}, 2009)$ Thus, translation is not only a language activity, but more a cultural activity. (Yuan, 2014) Translation provides a way for people with different language and cultural background to know more about other cultures, and it also serves as a platform for the communication among different cultures. (Yue, 2014)

\section{The nature of translation is culture integration}

Chinese study of translation and culture is mainly characterized by laying equal stress on both theory and practice. Scholars try to reveal the nature and purpose of translation in theoretical study, and also do researches on how to deal with cultural factors in translation practice. 
They analyze the result of translation activity -- translated text. By the analysis of the deep reasons about the ambiguities in translation, they conclude that translation activity is a process of cultural integration, and expound that the nature of translation is cultural integration.

In translation practice, no matter the translator prefers alienation or assimilation, translation text is always the integration of two languages and cultures. The influence of target culture to a piece of translation demonstrates that translation is not merely restricted by source language. If translation was studied only from the perspective of source language culture, the conclusion must be misleading. Translation is the integration of source language culture and target language culture. (Kong, 1995)

The process of translation is greatly influenced by both cultures. So far, Chinese scholars mainly discussed several cross-cultural factors in their studies including aesthetic orientation, political interference and ethical intervention, etc, providing further evidences to show that translation is greatly influenced by culture. Translation is more than a language activity. Every aspect of a culture will influence the translation process with varying degree according to the degree of cultural acceptance at that time, and affect translators' logical judgment and diction. (Wang, 1998) In this way, translation is definitely influenced by native culture as well as foreign culture, and it is the product of the joint influence of the two cultures.

Many of the Chinese scholars tried to expose the nature of translation from the perspective of modern linguistic theory. They firstly discussed the language phenomena which reflected cultural differences. From the points of semiology, and demonstrated that translation is a kind of social cultural phenomenon. Based on their research, the foundation of translation theory extended from the field of comparative linguistics to comparative cultural study. Generally, translation, as a communicative activity, conveys nothing but the cultural information of a society. (Luo, 1988) All the difficulties in translation process, including language barrier and cultural barrier, are caused by different symbolic behavior patterns of different culture. (Zhang, 1988) The study of the rules of language activity and the observation and discussion of the difference of symbolic behaviors in different cultural environment should be included in translatology. (Sui, 1994)

Then some Chinese scholars probed into the necessity of cultural transformation from the point of pragmatics. They analyzed culture from social, linguistic and science and technological and many other aspects, and proposed the ways to get equivalence in target language pragmatically. Because of the differences between two cultures, sometimes, appropriate cultural transformation is necessary in order to faithfully convey the pragmatic information to the target language readers. (Liu, 1989) The study of pragmatic translation mainly focuses on pragmalinguistic equivalence and sociopragmatic equivalence by the comparison between two languages. To achieve equivalent effect pragmatically in translation, translators should first make inference in accordance with the relevance between the utterance and the context and then achieve adequate contextual effect. (Mo, 2002) Translation is a kind of cross-language and crosscultural communicative activity. It is closely related to context in that the former is restricted by and depends on the latter. Context is the key of diction in translation. (Liang, 2015)

Lastly, inspired by the linguistic culturology in Russia, some Chinese scholars related the cultural factors embedded in language to the actual national condition, and pointed out that the purpose of translation is to represent appropriately in target language the meanings and implications of the objects in source language. Microcosmic 
study on translation and culture mainly involves the way to deal with cultural factors in translation. Specifically, it discusses the classification of cultural factors, methods and skills of translation and the requirement to translators etc. The universality and individuality of cultures exert great effect on translation practice. Different living conditions, customs, institutions, religious beliefs and people's different cognitions to the same objective world may give language different meanings and implications. (Tan, 1986) Among the studies on cultural comparison and translation study, most of the scholars adopt the same pattern, firstly analyzing the differences among cultures, and then proposing translation method or pointing out problems need to be noticed. Influence of different ways of thinking to translation (Zhang, 1999), Translation of names with special implication (Wang, 1993), and Translation of Title and Kinship Terms (Wen, 1994) are representatives of this kind.

\section{Cognition of the significance of cultural transplantation}

One of the purposes of translation study is to explore how translation can fulfill the role of a bridge between different languages and cultures. As is illustrated in the previous part, Chinese scholars concluded that the nature of translation is cultural integration. To put it into translation practice, the purpose of translation activity is to realize cultural transplantation. Translation includes the interpretation of foreign cultures. (Shao, 1987) The process of translation not only involves the superficial conversion between source language and target language. It is more about the interpretation of native culture and foreign culture. Communicating the cultural information faithfully in another language is indispensable in the process of translation. Translation is a kind of cultural and thinking transplantation rather than physical move from one place to another. (Li, 1988) Chinese scholar Li Guolin (1997) analyzed the English version of a well-known Chinese classic work "The Scholars" by famous Chinese translators, Yang Xianyi couple, and concluded the translation methods of the culture-loaded words in it. Illustrations showed that translation is not only a process of language transformation, but a process of culture transplantation.

In the whole linguistic system, vocabulary can best show the differences in culture. Thus, Chinese scholars tend to start their research on cultural difference and translation skills from lexical translation or phrase translation study. For example, Ke Ping (1988) described the non-equivalent phenomenon between source language and target language in denotation and pragmatic level on account of cultural difference; Cai Yi (1993) illustrated some representative culture-loaded words (non-equivalent words) and the translation methods, and he believed that those methods are applicable to translate other cultural factors; Wang Bingqin (1993) discussed the relationship between cultural connotations of words and translation, and expounded the cultural connotations of words; Feng Yulv (1993) studied the way of deciding appropriate meaning of words in translation from the point of cultural difference. While Chinese study on culture in translation doesn't only concentrate on written translation. Some scholars approached it from the perspective of oral interpretation.

In effect, people's intensive attention to cultural issues in translation originates from the correct cognition on the role of background knowledge to translation. It is by no means an easy job to represent cultural factors in translation process. Translators need to be sensitive to the cultural factors embedded in source language, and to decide the appropriate way to translate different cultural information. The most difficult problem in translation is caused by the very difference 
between two cultures. What is self-evident in one culture may need specific explanation in another. What seems natural to native speakers may need interpretation to make foreign readers to understand. (Wang, 1985) Translators should take the national colors of both languages into consideration in translation. Borrowed words and borrowed expressions will definitely enrich native language. Yet, readers' response should be highlighted in cultural transplantation. Translation should be in accordance with the rules of target language. (Shen \& She, 1994)

\section{The development of cultural translatology}

Since the introduction of cultural factors to the theoretical study of translation, two trends are formed among Chinese scholars. Some of them tend to renew their cognition on traditional translation theories, and some are active in exploring new theories of cultural translatology. Cultural translatology is an interdisciplinary subject. It is a new subject based on culturology, cultural linguistics and translatology. Judging from the status of and the relationship among the disciplines, Cultural translatology, translation linguistics and aesthetics of translation are three major branches of translatology. Wang Bingqin (1995), the writer of Cultural Translatology, which is the first theoretical work on the study of cultural translatology in China, established the new discipline from the perspectives of idealism, behaviorism and influence theory. Wang Kefei (1997) proposed a new term of history of translation culture. Derived from the ground of translation history, intellectual history and cultural history, it focuses on the significance and impact of translation on culture, especially on the target language culture. By examining translation activities in history, the study of the history of translation culture mainly centers around the various phenomena in the process of cultural communication, including changes in politics, economics, thinking, society, language and culture, etc, and probes into their influence on the development of people's ideology and culture.

China boasts a brilliant history in translation. We have traditional translation theories, excellent translation works, powerful ideological basis of eastern philosophy and aesthetics. There is enough evidence to show Chinese scholars' researches on culture and translation will undoubtedly inject new vitality to the world's theoretical study of translation, and play an active role in promoting the translatology in the world. However, despite the efforts of many Chinese scholars, from the future development of cultural translation, researchers should push cultural translatology forward systematically and comprehensively in addition to finding more angles to study this subject. Translators should work to contribute to a systematic and comprehensive study rather than on some simple and superficial ones.

\section{References}

Cai Yi (1993). Words, National Cultural Traits and Translation. Chinese Translators Journal, 1, 41-43, in Chinese.

Du Zhihua (2009). Translation and Cultural Difference from the point of Cross-culture Communication. Journal of Taiyuan Vocational College, 2, 151-152, in Chinese.

Feng Yulv (1993). Cultural Connotation of Words and Their Translation. Journal of Foreign Language, 1, 41-4 3, in Chinese.

Ke Ping (1988). Cultural Difference and Semantic Non-correspondence. Chinese Translators Journal, 1, 14-16, in Chinese. 
Kong Huiyi (1995). On the Significance of Translation as Products of TL Culture. Journal of Foreign Language, 3, 44-47, in Chinese.

Li Tairan (1988). Translation - Cultural Transplantation. Chinese Translators Journal. 2, 20-22, in Chinese.

Li Guolin (1997). Translation from Chinese into Foreign Language: A Medium of Chinese Cultural Communication. Chinese Translators Journal, 2, 30-32, in Chinese.

Liang Ze (2015). On the Syntagmatic and Paradigmatic relations between Translation and Context. Overseas English, 5, 214-215, in Chinese.

Liu Miqing. Modern Translation Theory. Jiangxi Education Press, 1990. 301p., in Chinese.

Liu Shan (1982). Translation and Culture. Translators Notes, 5, 5-8, in Chinese.

Liu Xiangang (1989). Cultural Translation and Pragmatics. Shandong Foreign Language Teaching Journal, 4, 51-54, in Chinese.

Mo Aiping (2002). Pragmatic Translation and Contextual Relevance. Journal of Hengyang Normal University, 8, 113-117, in Chinese.

Shao Hong (1987). Translation - Interpretation of Foreign Culture. Chinese Translators Journal, 6, 17-21, in Chinese.

Shen Baoji, She Xiebin (1994). Literary Translation and National Features. Foreign Language and Translation, 1, 12-15, in Chinese.

Sui Ran. Semiotic Perspective of Translation and Cultural Translation. Foreign Language and Their Translation, 1994, p. 36-39, in Chinese.

Tan Zaixi (1986). Cultural Comparison and Translation. Chinese Translators Journal, 5, 7-9, in Chinese.

Wang Bingqin (1993). Culture and Three Theories of Ji Xianlin. Foreign Language Teaching, 1, 17-22, in Chinese.

Wang Bingqin. Cultural Translatology. Nankai University Press, 1995. 313p., in Chinese.

Wang Dongfeng (1998). Cultural Intervention in the Process of Translation. Chinese Translators Journa, 5, 6-9, in Chinese.

Wang Kefei (1997). On the Classification of Translation Study. Translators Notes, 1, 52-55, in Chinese.

Wang Xiaoyuan (1993). Machine Translation of The Characters' Names in Literary Works". Chinese Translators Journal, 1, 10-11, in Chinese.

Wang Zuoliang (1984). Cultural Comparison in Translation. Translators Notes, 1, 2-6, in Chinese.

Wang Zuoliang (1985). Translation and the Prosperity of Culture. Translators Notes, 1, 6-8, in Chinese.

Wen Jun (1994). Translation of Social Deixis, Pragmatic Equivalence and Address Terms. Chinese Translators Journal, 5, 34-37, in Chinese.

Wu Zelin (1988). A Study on Cultural Integration in Literary Translation. Chinese Translators Journal, 1, 22-23, in Chinese.

Yan Fu. Evolution and ethics (Tr.). Shanghai World Book Publishing Company, 2013. 212p., in Chinese.

Yuan Jing (2014). A Study on the Relationship between Business English Translation and Cultural Difference. The Border Economy and Culture, 12, 107-108, in Chinese. 
Yue Hong (2014). An Analysis of Cultural Difference and Film Translation. Movie Literature, 6, 146-147, in Chinese.

Zhang Haitao (1999). Difference between Chinese and English Thinking Patterns on Translation. Chinese Translators Journal, 1, 14-18, in Chinese.

Zhang Yafei (1988). Symbolic System, Cultural Difference and Inter-lingual Translation. Chinese Translators Journal, 1, 17-21, in Chinese.

\title{
Перевод и культура глазами \\ современных китайских ученых
}

Мэн Ся

Шэньсиский педагогический университет 710062, Китай, Сиань, пр. Чанъанънанлу, 199

\begin{abstract}
С 80-х годов ХХ века вопрос о культуре все больше и больше вызывает внимания у китайского переводческого круга. На основе концепиии современного переводоведения ученые начали с аспектов культурологии, межкультурной коммуникации, культуролингвистики и др. изучать перевод и достигли немалых достижений. Под влиянием традииионной философской культуры китаец обращает много внимания на меру, как переводчик его субъективная осознанность бывает сдержанной. В Китае, после того как фактор культуры вошел в концепции перевода, многие ученые считают, что сбор информации и логический позитив должны быть совместными.
\end{abstract}

Ключевые слова: перевод и культура, слияние культур, аккультуращия.

Научная специальность: 10.00.00 - филологические науки. 